\title{
SYSTEMS OF INNOVATION AND ECONOMIC THEORY ${ }^{1}$
}

\author{
MARIO SCERRI ${ }^{2}$
}

\section{INTRODUCTION}

In the early 1980s Nelson and Winter (1982) addressed the question posed more than eighty years earlier by Veblen (1898) as to why economics was not an evolutionary science. The volume of collected work edited by Dosi and others (Dosi et al, 1988) brought together contributions from a wide range of theoretical positions and schools of thought on the relation between technological advance and economic change. Concurrently the concept of national systems of innovation emerged in the writings of Freeman (1982, 1987, 1995), Lundvall $(1985,1992)$, and Nelson (1993). This remains, to date, one of the more comprehensive attempts at formulating the conceptual framework of an account of the general economy as an alternative to that provided by mainstream economics. ${ }^{3}$ However, the promise held by the theoretical breakthroughs of the time has to a large extent not been fulfilled. Most of the research that followed focussed on a narrow interpretation of innovation as technology and its diffusion and deployment among private business enterprises. The narrow version of the system of innovation (Lundvall, 1992; Cassiolato and Lastres, 2000) is nowadays the most commonly used, implicitly restricting the approach to an alternative, albeit significant, account of a sub-sector of the economy.

If the system of innovation approach to economic dynamics were to be studied as an emerging discourse ${ }^{4}$ which alters the spaces of political economy, we will have to trace its genealogy and its various evolutionary paths. We will need to identify its common cause, its theme, and the counter-discourse against which it seeks its identity. We will have to chart its delineation lines, and its criteria for the inclusion of what are defined as its legitimate objects of analysis. If, to use Lundvall's term (Lundvall, 1992), the system of innovation approach can best be seen as a 'focussing device', we need to discern the direction of its lens and the outer limits of its focal range. The following section traces the origins of the system of innovation approach from List to Schumpeter in relation to

\footnotetext{
${ }^{1}$ An earlier version of this paper appeared as a 2018 IERI Working Paper WP2018-001, under the title 'Systems of Innovation and Economic Theory - a Genealogical Approach' and was presented at the Karl Mittermaier Symposium, The Johannesburg Institute for Advanced Studies, University of Johannesburg, $18^{\text {th }}$ March 2019. I would like to thank Dr Michael Stettler at the University of the Witwatersrand for his useful comments on the revised version of the paper. The usual disclaimer applies.

${ }^{2}$ Senior Research Fellow, Institute for Economic Research on Innovation, and DST/NRF Centre of Excellence in Scientometrics and STI Policy, Faculty of Economics and Finance, Tshwane University of Technology, Pretoria 0001, South Africa; email: mscerri@,outlook.com

${ }^{3}$ Lundvall (2016: 234) states in retrospect that apart from a study of innovation, the national systems of innovation concept 'was also seen as constituting an alternative analytical framework and a challenge to standard economics when it comes to explain competitiveness, economic growth and development.'

4 'In Foucault's analysis the notion of discourse is the primary unit. A discourse can be understood as a system of possibility for knowledge. This involves questioning the type of rules that permit certain statements to be made; the rules that govern these statements; the rules that allow us to identify some statement as true and some as false; the rules that permit the formulation of models and classificatory systems; the rules that permit individuals to be identified as authors; and the type of rules that emerge when an object of discourse is transformed or modified. The identification of sets of these kinds of rules represents a discursive formation or discourse.' (Variava, 2020: 32)
} 
the shifting core of mainstream economics. The section after that looks at the emergence of neoliberal economics as the mainstream and the relationship of the modern version of the system of innovation concept to this mainstream. The final section concludes with a brief appraisal of the current positioning of the system of innovation approach within economics and the possibilities for the fulfilment of its promise to become an alternative general theory of economics.

\section{THE CLASSICAL DEBATE}

The introduction of a systems approach to the study of political economy may be found in List's (1841) thesis on the 'national system of political economy', a harbinger of the national system of innovation. List had early on argued against the benefits of free trade advocated by Smith (1776) and Ricardo (1817). He maintained that the 'cosmopolitical' economy premised by Smith, Quesnay (1758) and Say (1821) in their argument for the welfare benefits of free trade was a utopian idealised world which bore little relevance to the reality of nations and nation states whose economic fortunes were the result of historical lines of path dependence and cumulative development (List, 1841: Ch. 11). He termed the study of these national economies as political economy in contrast to the cosmopolitical economy based on an assumption of a unified global economy devoid of contending national interests.

While List is probably best known for the 'infant industry' argument for protectionism, echoed a century later in the Prebisch-Singer thesis (Prebisch, 1950; Singer, 1950), the lines of his argument which have significant implications for the study of political economy are less remarked on in the history of economic thought. His policy departure from the core school of economics at the time was the bringing to the fore the role of the state in altering the development trajectories of national economies, a normative injunction which was diametrically opposite to the advocacy of intra- and inter-national free trade stemming from Smith. The contribution of List to economic thought rests on three fundamental objections to what he terms the 'popular school's:

firstly, ... boundless cosmopolitanism, which neither recognises the principle of nationality, nor takes into consideration the satisfaction of its interests; secondly, ... a dead materialism, which everywhere regards chiefly the mere exchangeable value of things without taking into consideration the mental and political, the present and the future interests, and the productive powers of the nation; thirdly, ... a disorganising particularism and individualism, which, ignoring the nature and character of social labour and the operation of the union of powers in their higher consequences, considers private industry only as it would develop itself under a state of free interchange with society (i.e. with the whole human race) were that race not divided into separate national societies. ((List, 1841, Vol. II: 70, bold added)

Levi-Faur (1997: 360) maintains that List may be seen as the "founding father of economic nationalism', a school of political economy which has, until relatively recently

\footnotetext{
5 This refers to classical liberal economists who were advocates of free trade. Early critics such as Nicholson (1909) accused List of distorting Smith's position on trade policy, ignoring his acknowledgement of the relevance of nations and setting him up as a straw man. Later commentators (Levi-Faur, 1997; Shafaeddin, 2000; Soete et al, 2010; Jun et al, 2016), while acknowledging List's combative tone and his occasional glossing over of Smith's reservations on the reality of nations, generally accept as correct his depiction of the theoretical position of the 'school' and its policy implications. It should be noted that List's critique of Smith and other related economists lays the foundation of the modern critical appraisal of the neoclassical and neoliberal economics, and of the Washington Consensus policy framework.
} 
been neglected in light of the dominance of the two contending economic schools of liberalism and socialism. List questioned Smith's focus on a theory of value, exchange value, as the explanation of the wealth of nations, proposing instead a theory of 'productive forces' based on the capacity of humans to work and innovate. Levi-Faur is correct in pointing this contribution out as the theoretical foundation of human capital theory which Foucault $(2004)^{6}$ postulates as the cornerstone of American neoliberalism, pioneered in the works of Mincer (1958), Schultz (1961) and Becker (1962). ${ }^{7}$ However, List's elaboration of his theory of productive forces goes considerably beyond the individual as the subject. In its emphasis of the critical role of social relations, of ideology ${ }^{8}$, of national power, and of history it opens the way for broader approaches to the role of the complexity of human relations and social formations in the fortunes of national economies, such as Sen's (1999) theory of human capabilities and to Marxian critiques of human capital theory (vide Bowles and Gintis, 1975). To fully appreciate the extent of List's theory of productive forces it is worth quoting at length a passage from his work (List, op. cit.: 29-30):

The present state of nations is the accumulation of all discoveries, inventions, improvements, perfections, and exertions of all generations which have lived before us; they form the mental capital of the present human race, and every separate nation is productive only in proportion in which it has known how to appropriate these attainments of former generations and to increase them by its own acquirements, in which the natural capabilities of its territory, its extent and geographical position, its population and political power, have been able to develop as completely and symmetrically as possible all sources of wealth within its boundaries, and to extend moral, intellectual, commercial, and political influence over less advanced nations and especially over the affairs of the world.

This passage from List highlights the complex combination of various factors which enter in the determination of the developmental capabilities of the national economy. More than that and especially significant not only for the system of innovation approach but for evolutionary economics in general, this passage brings in the critical importance of historical streams of accumulation in the determination of the fortunes of national economies. In his comparisons of the historical paths of the development of different European economies, List introduces the concepts of specificity, path-dependency and cumulative development which were to become the cornerstones of the system of innovation approach to economic dynamics. The focus on technology and knowledge, which, as Soete et al (2010) point out, is virtually exogenous to the economic system conceived by the neoclassical school, is echoed less than two decades later in Marx's Grundrisse.

\footnotetext{
${ }^{6}$ The concept of human capital is exemplified by Foucault (2004: 226) as 'Homo economicus is an entrepreneur, an entrepreneur of himself', which captures the eradication of the worker as a meaningful object of analysis, implicit in human capital theory.

${ }^{7}$ It is worth noting that in his 1978-1979 lectures on the evolution of neoliberalism at the Collége de France Foucault never mentions neoclassical economics. Foucault sees the main difference between classical liberalism and neoliberalism as a shift in focus from exchange to competition as the core of the economic system (Read, 2009).

${ }^{8}$ In List's case 'Christian religion, monogamy, abolition of slavery and vassalage, hereditability of the throne...' (List, 1841, Vol. II: 29)

9 'to the degree that large industry develops, the creation of real wealth comes to depend less on labour time and on the amount of labour employed than on the power of the agencies set in motion during labour time, whose 'powerful effectiveness' is itself in turn out of all proportion to the direct labour time spent on their production, but depends rather on the general state of science and on the progress of technology, or the application of this science to production.' (Marx, 1857-1861: 706)
} 
List particularly objected to Smith's 'invisible hand' theory which argues that the unfettered single minded pursuit of individual gain assures the maximisation of societal welfare, an outcome which is guaranteed by the forces of competition. ${ }^{10}$ This argument was then extended to the global economy in the advocacy for free trade policy, based on the presumed equivalence of the private family economy to the national economy. ${ }^{11}$ List's counter arguments formed the basis, not only for the case for protectionist policy in the case of unequal trading partners (the infant industry argument), but also for the critique against the school of economic individualism (Hayek, 1948; von Mises, 1949) which laid the foundation for the Chicago School version of neoliberalism. ${ }^{12}$ Soete et al (2010) unequivocally identify List as the progenitor of the national system of innovation concept with his emphasis on knowledge, broadly defined, accumulated over time as the outcome of linked interactive processes set within a framework of social and power relations, as the prime determining factor in the evolution of the fortunes of national economies. They see him as the pioneer in the development of a systemic approach to the understanding of political economy, spanning economic and non-economic sectors from an institutional perspective.

If Smith's classical economic liberalism was so very explicitly List's bête noire, it is not immediately obvious to discern the focus of Schumpeter's critical thought. The recurrent engagement throughout most of his work, culminating in his Capitalism, Socialism and Democracy (1943), with Marxian economics was an ongoing critique of various facets of Marx's work. However, read properly most of Schumpeter's critique of Marx was against a vulgar utopian and totalising version of Marxism. ${ }^{13}$ Substantively, there are numerous significant commonalities between Schumpeter and Marx in their analysis of capitalism. Both see capitalism as historically and spatially specific and both view the bourgeoisie as the font of innovation and human progress. ${ }^{14}$ Both authors also predict the eventual collapse of capitalism through processes which, while different, are inevitable and propose strikingly similar views on the dynamic (r)evolutionary nature of capitalism. ${ }^{15}$ However, Hodgson (2002) argues that, in spite of Marx's insistence on historical and locational specificity, Marxian economics cannot avoid the ahistorical, transcendental universality of its key concepts. Ironically, this places Marxian economics alongside neoclassical

10 ‘.... every individual ... generally, indeed, neither intends to promote the public interest, nor knows how much he is promoting it ... he intends only his own gain, and he is in this, as in many other cases, led by an invisible hand to promote an end which was no part of his intention.' (Smith, 1776: 572). This excerpt from Smith's single most quoted passage on the invisible hand has been widely debated in the literature. See, among others, Persky (1989), Hill (2001) and Harrison (2011) for discussions on the theological and natural science contexts of the concept. See Mittermaier (1986a) for a thorough discussion of Smith's own qualifications about the restrictive institutional underpinning of markets required for the convergence of private and public interest as posited by the invisible hand.

11 'It is the maxim of every prudent master of a family, never to attempt to make at home what it will cost him more to make than to buy.' (Smith, ibid: 759)

12 This in spite of the antipathy between the Austrian and neoliberal schools.

13 Schumpeter (1943: 385) is harshly dismissive in his first footnote: "The religious quality of Marxism also explains a characteristic attitude of the orthodox Marxist toward opponents. To him, as to any believer in a Faith, the opponent is not merely in error but in sin. Dissent is disapproved of not only intellectually but also morally. There cannot be any excuse for this once the Message has been received." This reservation was also expressed by several Marxist academics, as for example in Jessop (2002: 22) who “...raises questions about the conditions under which accumulation can become the dominant principle of societal organization (societalization). For there are always interstitial, residual, marginal, irrelevant, recalcitrant and plain contradictory elements that escape subordination to any given principle of societalization and, indeed, serve as reservoirs of flexibility and innovation as well as actual and potential sources of disorder."

14 'The bourgeoisie, during its rule of scarce one hundred years, has created more massive and more colossal productive forces than have all preceding generations together' (Marx and Engels, 1848: 7).

15 'There is more "Schumpeter" in Marx's writings than many Marxists are willing to accept, and more "Marx" in Schumpeter's analysis than even Schumpeter was willing to recognize.' (Elliot, 1980: 45-46) 
economics as universal meta-accounts of the general economy ${ }^{16}$ and this perhaps is where Schumpeterian and Marxian economics part ways.

More fundamentally, it was the Lausanne school of general equilibrium economics, established in the late nineteenth century by Walras (1899) and Pareto (1897), which constituted the emerging dominant school against which Schumpeterian economics is set. The high level of abstraction of neoclassical economics, divesting economic agents of historical, spatial and cultural contexts, combined with the extremely restrictive assumptions of full and perfect information places the neoclassical paradigm as diametrically opposite as one can get to Schumpeter's understanding of economic dynamics. Schumpeter was probably the first consistently critical anti-equilibrium economist who implicitly discarded comparative static analysis and Paretian welfare prescriptions. ${ }^{17}$ It is therefore ironic that Schumpeter's work was still strongly anchored in the neoclassical paradigm which, especially since Alfred Marshall's Principles of Economics (1890), had already become the dominant language of economics. The first section of The Theory of Economic Development is basically a general equilibrium depiction of a static economy. His critique of Marx's labour theory of value (Schumpeter, 1943: 21) states that it would only work under conditions of perfect competition, i.e. where the value of the marginal product of labour is equal to its marginal revenue product and to its marginal cost which under the neoclassical construct of perfect competition is a constant. Schumpeter also states that labour would have to be the only factor of production and it would have to be uniform for the labour theory of value to hold.

It is almost as if Schumpeter is not fully aware of the enormity of the promise of a rupture with established thought on economics held out by his theory of economic dynamics. As a consequence, Schumpeter's contribution can still be read, using neoclassical language, as endogenizing factors which were previously thought of as exogenous causes for an outward shift in the production possibilities frontier, rather than an outright dismissal of the conceptual framework behind it. It is worth noting that when Schumpeter lists the sources (types) of innovation he almost always refers to them as 'new combinations ${ }^{18}$ adhering to the language of choice under conditions of scarcity rather than opening up to the possibility of questioning scarcity as a meaningful consideration in the understanding of the limits to development.

Schumpeter's classification of 'new combinations' (innovation) is worth reproducing in its entirety (ibid: 66):

\footnotetext{
16 Neoclassical economists attempt to construct a universal framework of socio-economic analysis but end up viewing the universe through the distorting lenses of a specific type of economic system. The universality of their alleged universal principles is thus questioned. Marx, on the other hand, knowingly reacts from this kind of approach and attempts to site his analysis of specific systems on specific concepts appropriate to that system. Yet, contrary to his own arguments he ends up relying on theories and concepts that are in fact universal. Neoclassical economics aspires to universality but ends up being specific; Marxism aspires to specificity but ends up relying on the general.' (Hodgson, 2002: 211)

17 Pitelis and Runde (2017: 679) succinctly capture the critical distinction between neoclassical and classical economics as being 'about the efficient allocation of scarce resources, rather than about resource creation and the creation and distribution of wealth as advocated by classical economists such as Adam Smith, David Ricardo and Karl Marx.'

18 Schumpeter (1934: 65-66) anticipates the classification of innovations between incremental and radical, at least, and opens the possibility for the consideration of techno-economic paradigm shifts (Freeman and Perez, 1988) when he states that 'To produce means to combine materials and resources within our reach. To produce other things, or the same things with a different method, means to combine these materials and forces differently. In so far as the "new combination" may grow out of the old by continuous adjustment in small steps, there is certainly change, possibly growth, but neither a new phenomenon nor development in our sense. In so far as this is not the case, and the new combinations appear discontinuously, then the phenomenon characterising development emerges.'
} 
(1) The introduction of a new good - that is one with which consumers are not yet familiar - or a new quality of a good. (2) The introduction of a new method of production, that is one not yet tested by experience in the branch of manufacture concerned, which need by no means be founded upon a discovery scientifically new, and can also exist in a new way of handling a commodity commercially. (3) The opening up of a new market, that is a market into which the particular branch of manufacture of the country in question has not previously entered, whether or not this market has existed before. (4) The conquest of a new source of supply of raw materials or half manufactured goods, again irrespective of whether this source already exists or whether it has first to be created. (5) The carrying out of the new organisation of an industry, like the creation of a monopoly position (for example through trustification) or the breaking up of a monopoly position.

There are three critical aspects of Schumpeter's thought on innovation which arise from this excerpt. In the first place, the introduction of disruptive innovations as the source of creative destruction and development marks a radical theoretical break with the static and comparative static analysis of neoclassical economics. Secondly, the site of innovation as the source of economic development is confined to private enterprises, affirming capital as the engine of progress and development (vide Nelson, 1990). In this regard it is worth noting Sweezy's commentary on Capitalism, Socialism and Democracy, where he concludes that Schumpter's '... selection of the entrepreneur, a special sociological type, as the primum mobile of change can be called into question. We may instead regard the typical innovator as the tool of the social relations in which he is enmeshed and which force him to innovate on pain of elimination' (Sweezy, 1943: 96). Thirdly, within the context of private enterprise Schumpeter's understanding of innovation is remarkably comprehensive. Schumpeter's first two types of innovation refer directly to technological innovations (product and process), although the second one also opens up the consideration of marketing strategy as innovation. The other three categories refer specifically to non-technological innovations, dealing with various aspects of business strategy. It is interesting that the flow of theoretical work on the economics of innovation which emerged from Schumpeter's contribution focussed almost entirely on technological innovations. Only with the introduction of the system of innovation concept in the 1980s and the broad version of the concept (Lundvall, 1992) was a comprehensive version of the national system of innovation introduced in a theoretically systematic manner.

\section{DISCIPLINE AND DISCOURSE}

Given that the foundation of the new approach to the understanding of innovation and economic change was set as a counter to the mainstream neoclassical paradigm, it is important at this stage to examine certain core aspects of the dominant voice which defined the discipline of economics. If the ideal of scientific probity in the social sciences was linked to the natural sciences, the epitome of scientific endeavour for economics towards the end of the nineteenth century was to be found in Newtonian physics which had at that time, before the scientific revolution stemming from the work of Max Planck and Albert Einstein, so comprehensively explained the known universe that physicists were concerned that there was nothing of significance left to discover about the physical world. The ambition to achieve a scientific equivalence in economics was fulfilled in the formulation of the general equilibrium model of the economy developed by Walras and the Lausanne school, with the underlying general optimality conditions provided by Vilfredo Pareto. This enterprise required the shedding of all but the simplest behavioural assumption guiding economic agents classified as consumers, firms and labourers. 
Action, for every category of agent, is determined by the same marginal cost-benefit principles to the extent that all agents, be they producers or consumers ${ }^{19}$, are in the business of production, whether of goods and services or of utility, guided by the same equimarginal principle of optimisation. This general model, consisting of sets of simultaneous equations for consumption, production, and consumption and production combined, is used to derive a unique solution which represents the economy-wide optimal allocation of resources to reach the maximum level of welfare, given resources and technical knowledge, all of which are exogenous to the system.

Hayek (1942) was disdainful of neoclassical economics, viewing it as yet another example of the lamentable creep of scienticism ${ }^{20}$ over the social sciences and, in the specific case of the neoclassical general equilibrium model, a type of tautology. This he succinctly explains in a brief paragraph:

If we possess all the relevant information, if we can start out from a given system of preferences, and if we command complete knowledge of available means, the problem which remains is purely one of logic. That is, the answer to the question of what is the best use of the available means is implicit in our assumptions. The conditions which the solution of this optimum problem must satisfy have been fully worked out and can be stated best in mathematical form: put at their briefest, they are that the marginal rates of substitution between any two commodities or factors must be the same in all their different uses. (Hayek, 1945: 519)

This dismissive attitude has not critically entered the mainstream of debates on the neoclassical model and the consequence of this is a confusion which has grown over generations of economists trained under the auspices of the neoclassical paradigm about the theoretical core of equilibrium theory in general. Mittermaier (1986a: 56) clearly outlines the lines of this confusion when he says that

Some economists treat equilibrium theory as an ideal conception with the normative meaning and others treat it as a description in some attenuated sense and yet others distinguish very poorly between the two. Some see it as an ideal system worth examining because it is taken, perhaps mistaken, to be the system economic liberalism advocates; others see it as one element in a projected though as yet unexplained series of successive approximations to the working of actual economies. Some treat equilibrium theory as a study of the conditions for one or other kind of economic efficiency, such as the optimum allocation of resources or simply market clearing; others treat it as a handy framework for explanations and predictions of what actually goes on, perhaps on the grounds that people never fail to meet the efficiency conditions, or fail in a predetermined way.

Apart from this confusion of the meaning of equilibrium theory, the extreme restrictiveness of the assumptions that it requires, especially that of full information in all the varieties of this notion, renders it utterly useless for the understanding of the source and effects of innovation. It is therefore quite legitimate to base a theory of innovation,

\footnotetext{
${ }^{19}$ See Lancaster (1966) for the development of a production function approach to consumer behaviour.

20 'the tyranny commenced which the methods and technique of the Sciences in the narrow sense of the term have ever since exercised over other subjects. These became increasingly concerned to vindicate their equal status by showing that their methods were the same as those of their brilliantly successful sisters rather than by adapting their methods more and more to their own particular problems. And although in the hundred and twenty years or so, during which this ambition to imitate Science in its methods rather than its spirit has now dominated social studies, it has contributed scarcely anything to our understanding of social phenomena, not only does it continue to confuse and discredit the work of the social disciplines, but demands for further attempts in this direction are presented to us as the latest revolutionary innovations which, if adopted, will secure rapid undreamed of progress' (Hayek, 1942: 268).
} 
set within the fold of evolutionary economics, in an explicit refutation of the suitability of neoclassical economics for this task. Moreover, as the understanding of innovation in the 1980s came to match that of the classical economists of the nineteenth and early twentieth centuries, innovation theory progressed from a dissident analysis of a sector of industrialised economies to a more generic attack on mainstream theory. However, it is at this stage that confusion again arises, this time as to the exact nature of the countervailing discourse and it is here that the conflation of neoclassical and neoliberal economics becomes deeply problematic.

There have been numerous accounts of the development of neoliberal economics, but most of these accounts boil down to a description of the basic tenets of this school. These are mostly in terms of its assumption of the primacy of a simplistic version of the invisible hand in assuring the optimal coordinating mechanism for the general economy, with a restriction of the role of the state to the safeguarding of property rights and the correction of infrequent cases of 'market failure'. Most accounts also focus on the historical development of neoliberalism and its eventual hegemonic position over global economic policy formulation. The various trajectories of the evolution of neoliberal economics are also often traced with variations of interpretation across space and time. Rarely however is the distinction between liberal and neoliberal economics explored in detail. This is to some extent due to the blurring of the demarcation lines between the general policy advocacies of these two schools. The distinction between ordo-liberalism and anarcholiberalism discussed by Foucault (2004), among others, points out a major divergence between the liberal and neoliberal schools, both in the theoretical positioning of state visa-vis market and their contextual location through the middle to late twentieth century history. ${ }^{21}$

There is however another fundamental distinguishing factor which has not been sufficiently explored. We may discern this distinction by contrasting Hayek's (1942, 1943, 1944, and 1945) treatise on the encroachment of scienticism in the study of society and the theoretical and analytical emptiness of the neoclassical paradigm with the emergence of the standard microeconomics textbook, starting with Robbins' (1932) text which led to the consolidation of the neoclassical textbook in its current form with the flurry of textbooks coming out in the late 1950s and early 1960s. This text which has come to be the undisputed and totally exclusive tome in the teaching of undergraduate economics contains the whole array of neoclassical models drawn into the service of a neoliberal advocacy of free markets, in disregard of the fundamental theoretical incompatibility between the neoclassical and liberal theoretical bases. This incompatibility is evident in every aspect of the neoclassical text, especially in the corruption of language evident in the word 'competition'. McNulty (1968) points out that the neoclassical models of perfect competition, monopoly and variations of oligopoly exclude, through assumption, any vestige of competitive behaviour. In fact, these models exclude the entrepreneur since in a perfectly known world all that is needed for optimal decision making is the computer. This is in contrast to Stigler (1957) who, in the same vein as Machlup's (1967) defence of marginalism in the depiction of the profit-maximising firm, argues that perfect competition is at the same time the most rigorous and most tractable model of competitive markets available to the economist. Machlup, almost casually, brushes aside critical contributions which introduced behavioural and organisational theories of firm

\footnotetext{
${ }^{21}$ See Foucault's (2004) tracing of the bifurcation of the evolution of liberal economics into ordoliberalism which was at the core of Germany's post-war economic restructuring and subsequent policy and anarcho-liberalism which was the neoliberalism emerging from the Chicago school. See also Streeck and Yamamura (2001) for an exhaustive distinction between the two main varieties of capitalism which emerged in the post-war era.
} 
behaviour ${ }^{22}$ and consumer behaviour ${ }^{23}$ as essentially cumbersome in comparison to the single objective/full information neoclassical theory of the firm. This insistence on the translation of equilibrium theory into an analytical portrayal of actual competitive behaviour and consumer decisions is disingenuous, and it can therefore only be read as an opportunistic claim for the scientific integrity conferred by the mathematics of neoclassical economics to validate libertarian ideology in the tradition of the Chicago School. This anomaly is most evident when we consider that the obvious normative implication of the full information general equilibrium model that the optimal coordination mechanism should be a centrally planned economy where the optimal allocation of resources would never be subject to the vagaries of markets and human agency. Instead, the perfect competition model has been used as the 'scientific' rationale for the support of free markets and the minimal state by the Chicago school which would eventually extend marginalist theory to explain all of human behaviour, thus laying claim to the status of an 'imperial science' for the hybrid (Stigler, 1984; Becker, 1996).

The thrust of the arguments for the enlisting of neoclassical economics in the service of a neoliberal agenda centres around the 'as if' argument ${ }^{24}$ proposed in the analogies of Friedman's (1953) billiard player and Machlup's (1967) automobile driver. Both Friedman and Machlup take care to avoid what Machlup calls the 'fallacy of misplaced concreteness ${ }^{25}$ by arguing that optimisation models were never meant to correspond to real life but were, in Machlup's words, the outcome of the application of Occam's Razor where a high degree of abstraction trimmed off empirical considerations which were superfluous to the requirements of predictive models aimed at tracing the effects of exogenous changes such as taxes or interest rates on market behaviour. Lundvall (2016: 238) makes the critical point that

'the most important weakness of neoclassical theory is not that it is too abstract. It is rather that it makes the wrong abstractions. In a context where knowledge is the most important resource and learning the most important process, neoclassical theory tends to abstract from the very processes that make a difference in terms of the economic performance of firms and for the wealth of nations.'

Analogies, unlike examples, can be dangerously misleading when called up in the cause of theoretical reasoning. Both the billiard player and the automobile driver are, specifically in their respective roles, decision makers driven by a single objective and making decisions in a fully known universe. To use these examples as useful analogies representing real life agents who are driven by multiple objectives, of different provenance and often contradictory, operating in a context which is marked by non-actuarial risk which grows along with ignorance as decisions and the envisaged consequences of those decisions

\footnotetext{
22 See Simon (1959), Cyert and March (1963), March and Simon (1993), and Williamson (1985) for behavioural, managerial and organisational theories of the firm. Nelson (1991) laments the side-lining of these theories of firm behaviour from the core of economics.

${ }^{23}$ See Stigler and Becker (1977) for the rationale for the theoretical dismissal of tastes and preferences as given in the analysis of consumer and other human behaviour.

24 'It is only a short step from these examples to the economic hypothesis that under a wide range of circumstances individual firm behave as if they were seeking rationally to maximize their expected returns (generally if misleadingly called "profits") and had full knowledge of the data needed to succeed in this attempt; as if, that is, they knew the relevant cost and demand functions, calculated marginal cost and marginal revenue from all actions open to them, and pushed each line of action to the point at which the relevant marginal cost and marginal revenue were equal.' Friedman (1953: 13)

${ }^{25}$ Following Whitehead (1925) and Robbins (1932), Machlup (1967: 9) explains the fallacy as follows: "To confuse the firm as a theoretical construct with the firm as an empirical concept ... is to commit the 'fallacy of misplaced concreteness'. This fallacy consists in using theoretical symbols as though they had a direct, observable, concrete meaning."
} 
stretch into the future, is a deeply flawed exercise. Reservations raised by the consideration of the actual object of study are brushed aside as essentially trivial specifics which do not affect the core principle of presumed behaviour on the basis of the 'as if assumption or by the argument that, regardless of flaws, the neoclassical theory of the firm is the best approximation to real life entities. The casual reference to the mechanical metaphor underlying neoclassical economics opens up to the syndrome best described by the term 'mechanomorphism' coined by Mittermaier (1986b). ${ }^{26}$ Mittermaier cautions against the easy dismissal of metaphors as a mere figure of speech when he says that 'they are more than mere expressions. They involve conceptions of the nature of economic affairs and consequently also certain attitudes of mind when economic questions are dealt with' (Mittermaier, ibid: 238).

The question that should be raised at this point is the level to which abstraction can be pushed before the distance from empirical reality fatally compromises not just the explanatory power but also the predictive capability of theoretical constructs. The neoclassical paradigm constitutes one of the more extreme examples of abstraction, offering as it does a fully determined closed logical construct of the economy which could provide unique optimisation solutions to the problem of the allocation of scarce resources. The critical issue here is whether neoclassical economics with the general equilibrium model at its core is amenable to adaptation and loose interpretation in the manner of neoliberal economists. The answer has to be unequivocally that it cannot. The neoclassical model is so completely specified and so dependent on this complete specification for its integrity that that any violation would negate the whole paradigm. Without full and perfect information (including probability values assigned to future possible outcomes) it would be impossible to derive continuous objective and constraint functions and thus say anything about allocation and constrained optimisation. The reason why the neoclassical model of the economy does not relate to empirical facts is fundamentally because it is not designed to do so. It is an extreme example of deductive reasoning, conceptually elegant in its mathematical rendition and useful as an exercise in logic, which cannot allow for approximations to its ideal state.

Neoclassical economics is quite incompatible with the study of political economy, presenting as it does a mathematical model of the national economy which is fully specified and designed to contain solutions to the model in the predetermined fashion of Hayek's (1945) depiction. The 'as if proposition of Friedman and Machlup is the legerdemain which implicitly justifies the neoclassical text as the basis for the understanding of economic life and the theoretical validation of a fundamentally libertarian normative position. This twinning of two incompatible theoretical corpuses is the hallmark of neoliberal economics, highly successful in its hegemony over the undergraduate text (Scerri, 2008) and across policy environments across the world, but fundamentally flawed as theory. This hegemony has constituted neoclassical economics as the discipline of economics, but the contradiction is that the neoliberal gambit which enabled this elevation violates, through its blurring of the demarcation lines between discursive formations, the primary requisite of exclusion as articulated by Foucault (1970) which specifies the limits of what can belong to a discipline. ${ }^{27}$ The relationship between the discipline as neoclassical economics and the discourse as neoliberal economics violates the tenet set

26 '... an economist engages in mechanomorphism when he ascribes mechanical properties to what is otherwise recognized as part of human affairs or when he treats an economic system as though it were a mechanical system.' (Mittermaier, 1986b: 237)

27 "a proposition must fulfil complex and heavy requirements to be able to belong to the grouping of a discipline; before it can be called true or false, it must be 'in the true', as Canguilhem would say ... one is 'in the true' only by obeying the rules of discursive 'policing' which one has to reactivate in each of one's discourses ..." (Foucault, 1970: 60) 
out by Foucault that '...(t)he discipline is a principle of control over the production of discourse. The discipline fixes limits for discourse by the action of an identity which takes the form of a permanent re-actuation of the rules' (Foucault, ibid: 61). In this sense, it is neoliberal economics which forms the mainstream discourse ${ }^{28}$ while flouting the restrictions imposed by the neoclassical paradigm which it uses as its disciplinary base. Ironically, this hybrid is vulnerable to the charge that 'anything goes' which is often levied against pluralist economics. The apparently monist position of the hybrid as mainstream economics is not one of theoretical coherence but rather the outcome of power. ${ }^{29}$

Nelson and Winter (ibid) and Nelson (2007) propose that research in economics tends to run along two linked but distinct tracks which they term formal and appreciative theory. ${ }^{30}$ Formal theory stands in for the discipline of mainstream economics while appreciative theory in practice, or praxis, forms the discourse of economics as it is generally accepted. Thus, while formal theory in the mainstream is still neoclassical economics, appreciative theory - the way economics is 'done' and informs policy - has been formed by the neoliberal doctrine.

Appreciative theory is difficult to engage with theoretically. It is ephemeral, with a fluid positioning vis-à-vis its underlying base in formal theory, an essentially instrumentalist approach, and an easy adoption of ex post facto justifications for its predictive failures. In the world of prediction and prescription, instrumentalism is the unquestioned norm of practice. In the process the fundamental incompatibility between discipline and discourse in mainstream economics is forgotten or easily dismissed, and an implicit ideological agenda with its associated exercise of power, determines the shape and direction of the mainstream.

\section{PROSPECTS}

The theoretical problems of the neoliberal hybrid are immeasurably amplified with its consolidation as the mainstream of the discipline, as formative of its main discourse against which alternative accounts have to be measured. This is clearly evident with the emergence of the system of innovation approach as a potential alternative general account of the economy. There is hesitation in refuting the emerging neoliberal orthodoxy in its totality in Schumpeter's case as discussed earlier. Nelson and Winter (1982) still accord the orthodoxy central pace as far as static analysis is concerned. Lundvall has to repeatedly interrogate the eligibility of the system of innovation approach for the status of theory, again measuring it up against the determinate mathematical articulation of the neoclassical paradigm and settling for the description of the approach as a 'focussing device' (Lundvall, 2010, Ch. 10; 2016: Ch. 4).

28 'neoliberalism works to efface the fundamental division between worker and capitalist, between wages and capital, through the production of neo-liberal subjectivity. Neoliberalism is a discourse and practice that is aimed to curtail the powers of labour that are distributed across all of society-at the exact moment in which all of social existence becomes labour, or potential labour, neoliberalism constructs the image of a society of capitalists, of entrepreneurs.' (Read, 2009: 33)

${ }^{29}$ See Harvey (2005), among others, for an account of the ascendancy of the Mont Pelerin Society in the major global and national economic policy spheres.

${ }^{30}$ Nelson points out the "difference between ... 'appreciative' and 'formal' theory, with the former mostly expressed verbally, and much closer to the empirical details of the subject matter than the latter, and the latter articulated more abstractly, often in the form of a mathematical model, and more amenable to logical exploration and manipulation. While current use of the term 'theory' in economics has tended to identify with formal theory, ... in economics most of the empirical research and interpretation of empirical phenomena, was structured by appreciative theory.' (Nelson, 2007: 20-21) 
Nelson (2007) emphasises the need for evolutionary approaches to innovation and development to coalesce into a coherent body of formal theory which can act as an alternative reference point for a practice of an appreciative theory which is more appropriate to rapidly changing economies. However, the acceptance of the practice of appreciative theory can be problematic in the case of neoclassical economics which is so completely mathematically defined that it has little leeway for departures from its highly restrictive assumptions regarding information and the definition of economic agents. The implicit allowance that neoclassical economics is suited for static or comparative static analysis may also be questioned. From an evolutionary perspective, economies are always in a state of flux with periods of apparent stability occasionally, and often briefly, emerging as a resultant of a temporary balance of the myriad contending forces and tendencies which form the national and global political economy. One can justifiably argue that the practice of appreciative theory has become the vehicle for the usurpation of the mathematical validation of the neoclassical paradigm by neoliberal economics. The appeal to commonly perceived empirical reality as formative of research practice lays the discipline open to the dangers of adopting 'common sense' as a guiding principle for positing behavioural relations. ${ }^{31}$ Evidence-based research and the normative implications of such research in the absence of a clear and unambiguous reference to the theoretical foundation of the research tend to result in a confusion of theoretical languages. When it comes to interpreting the world, evidence is meaningless without the theoretical lens and it is the clear specification of the theoretical lens which often determines which empirical observations count as evidence and which are trivialised as 'noise'. Without this clear specification of the theoretical base for a research agenda, the choice of evidence itself often serves to reinforce a dominant discourse and its concomitant power relations. ${ }^{32}$ In the case of innovation in general, and the system of innovation in particular, the adoption of appreciative theory has in many cases allowed a persistent contradiction with the retaining of the critique of neoclassical economics alongside the implicit acceptance of neoliberal economics, with the latter negating the former.

In this slippage in the identification of its counter-discourse, the system of innovation approach has as yet failed to develop a coherent discursive formation which can challenge the mainstream account of the economy. ${ }^{33}$ In light of this, it is difficult to contest the assessment of Fine and Rustomjee (1996: 244) when they propose that the '(national system of innovation) framework is unduly descriptive in content, merely pointing to the various institutional components driving technical change, albeit breaking with received notions in orthodox economics'. Winter (2017: 739-740) is also dismissive of the explanatory power of system of innovation concept when he says that '(n)ational innovation 'systems' are generally more of a congeries than a system, if "system" is taken to imply a logically coherent structure. They reflect the accumulation of responses to

31 'Common sense is constructed out of long standing practices of cultural socialisation...(It) can, therefore, be profoundly misleading, obfuscating or disguising real problems under cultural prejudice’ (David Harvey, 2005: 39, citing Gramsci).

32 Hacking (1991: 181) captures the essential non-neutrality of evidence, in this case statistical evidence, in a distinctly Foucauldian manner when he proposes that '(s)tatistics has helped determine the form of laws about society and the character of social facts. It has engendered concepts and classifications within the human sciences. ... It may think of itself as only providing information, but it is itself part of the technology of power in the modern state.'

${ }^{33}$ Variava (2020: 33) succinctly summarises Foucault's guidelines for the recognition of discursive formations: 'a discursive formation is identifiable if the statements in it refer to the same object; a discursive formation has a regular 'style', a common way in which statements are made; a discursive formation is identifiable if the concepts in the statements have a constancy; a discursive formation exists if all the statements support a common theme, or what Foucault calls in his later books a 'strategy', a common institutional or political pattern'. 
relatively specific policy issues, but the impact of those responses may extend very widely.' This interpretation of the 'system' from an organisational perspective obviously would see severe theoretical limitations of the system of innovation concept but this ignores the fundamentally biological metaphor of the approach where a system of innovation is not necessarily, in fact rarely, something which is planned. Systems of innovation evolve organically, whether planned or not, sometimes in spite of planning. They may thrive or falter and sometimes they may die out, and it is this interpretation of the 'system' which may open up the possibility of a new theoretical approach to the understanding of economies, at the national, sub-national, or supra-national levels.

The relationship between formal and appreciative theory is gravitational with the practice of economics subtly and often imperceptibly serving to affirm the dominant discourse. The system of innovation approach has yet to develop a comprehensive alternative general theory of the economy and is at best seen as a, often case-study based, contribution to a sub-sector of an economy implicitly formed by the language of neoliberal economics. Perhaps the starting point for the development of an alternative account of the general economy may be found in Lundvall's 1992 definition of the national system of innovation as '... the elements and relationships which interact in the production, diffusion and use of new, and economically useful, knowledge ... and are either located within or rooted inside the borders of a nation state' (Lundvall, 2010: 2). This particular definition is notable on two main issues. The first is the emphasis on knowledge rather than technology. The second is the reference to the institutional underpinning of the system of innovation in terms which allow for the whole gamut of formal and informal institutions and, by implication, the introduction of a significant degree of specificity in the study of systems of innovation. Lundvall (2016: 224) emphasises the essential requirement to adopt the broad definition of the system of innovation when he says that '(w)ithout a broad definition of the national innovation system encompassing individual, organizational and interorganizational learning, it is impossible to establish the link from innovation to economic growth'.

The development of an alternative general theory of the economy could be built on three closely inter-linked pillars. The first is a revisiting of the theory of value, essentially re-articulating the labour theory of value as an innovation theory of value. A broad enough interpretation of innovation would read all human economic activity, manifest in goods, services and experience, as current innovation or as the embodiment of historical streams of innovation. This re-visiting of value would also help to revitalise the challenge to an exchange theory of value which implicitly runs through the mainstream discourse, even when exceptions are permitted as 'market failure'. The second foundation for an emerging discourse would be to anchor systems of innovation in specific accumulation regimes. Boyer (1988) provided an enticing prospect of the theoretical possibilities of this pursuit, more fundamental than the complementing of the study of the national system of innovation by the specification of a particular type of capital accumulation, as proposed by Fine and Rustomjee (1996). The third pillar would be the conceptual extension of the informal institutional and tacit knowledge base to permeate and ultimately define systems of innovation. This would entail the drawing in of traditional sociology and modern anthropology, and interpretative historical reading within a political economy theoretical framework of evolutionary economics. 


\section{REFERENCES}

BECKER, G.S. (1962). Investment in Human Capital: A Theoretical Analysis. Journal of Political Economy 70 (5): 9-49.

BECKER, G.S. (1993). Nobel Lecture: The Economic Way of Looking at Behaviour. Journal of Political Economy, 101 (3): 385-409.

BOWLES, S. and GINTIS, H. (1975). The Problem with Human Capital Theory - A Marxian Critique. The American Economic Review, 65 (2): 74-82.

BOYER, R. (1988). "Technical Change and the Theory of Régulation.” in Dosi et al (eds): 67-94.

CASSIOLATO, J.E. and LASTRES, H.M.M. (2000). Local Systems of Innovation in Mercosur Countries. Industry and Innovation 7 (1): 33-53.

CYERT, R. M. and MARCH, J.G. (1963). A Behavioural Theory of the Firm. Englewood Cliffs, N. J.: Prentice-Hall.

DOSI, G., FREEMAN, C., NELSON, R., SILVERBERG, G. and SOETE, L. (eds) (1998). Technological Change and Economic Theory. London: Pinter.

ELLIOT, J. T. (1980). Marx and Schumpeter on Capitalism's Creative Destruction: A Comparative Restatement. Quarterly Journal of Economics 95 (1): 45-68.

FINE, B. and RUSTOMJEE, Z. (1996). The Political Economy of South Africa: From MineralEnergy Complex to Industrialisation. Johannesburg: University of the Witwatersrand Press.

FOUCAULT, M. (1970). The Order of Discourse (Inaugural Lecture at the Collège de France)." in Young, R. (ed) (1981): 48-78.

FOUCAULT, M. (2004). The Birth of Biopolitics: Lectures at the College de France 1978-1979. Hampshire: Palgrave Macmillan.

FREEMAN, C. (1982). Technological Infrastructure and International Competitiveness. Draft paper submitted to the OECD Ad hoc-group on Science, Technology and Competitiveness.

FREEMAN, C. (1987). Technology Policy and Economic Performance: Lessons from Japan. London and New York: Frances Printer Publishers.

FREEMAN, C. (1995). The 'National System of Innovation' in Historical Perspective. Cambridge Journal of Economics 19: 5-24.

FREEMAN, C. and PEREZ, C. (1988). "Structural Crises of Adjustment: Business Cycles and Investment Behaviour." in Dosi et al (eds.): 38-66.

FRIEDMAN, M. (1953). "The Methodology of Positive Economics." in Friedman, M. Essays in Positive Economics: Chicago, University of Chicago Press: 1-37.

HACKING, I. (1991). "How should we do the History of Statistics?", pp. 181-196, in Burchell, G., Gordon, C., and Miller, P. (eds.) The Foucault Effect: Studies in Governmentality, Hertfordshire, Harvester Wheatsheaf.

HARRISON, P. (2011). Adam Smith and the History of the Invisible Hand. Journal of the History of Ideas 72 (1): 29-49.

HARVEY, D. (2005). A Brief History of Neoliberalism. New York: Oxford University Press. HAYEK, F.A. (1942). Scientism and the Study of Society, Part I. Economica 9 (35): 267291.

HAYEK, F.A. (1943). Scientism and the Study of Society, Part II. Economica 10 (37): 3463.

HAYEK, F.A. (1944). Scientism and the Study of Society, Part III. Economica 11 (41): $27-$ 39.

HAYEK, F.A. (1945). The Use of Knowledge in Society. The American Economic Review 35 (4): 519-530.

HAYEK, F.A. (1948). Individualism and Economic Order. Chicago: The University of Chicago Press. 
HILL, L. (2001). The Hidden Theology of Adam Smith. European Journal of the History of Economic Thought 8(1): 1-29.

HODGSON, G.M. (1998). On the Evolution of Thorstein Veblen's Evolutionary Economics Cambridge Journal of Economics 22: 415-431.

HODGSON, G.M. (2002). "Varieties of Capitalism and Varieties of Economic Theory." in Hodgson, G.M. (ed.), A Modern Reader in Institutional and Evolutionary Economics. Cheltenham: Edward Elgar: 201-230.

JESSOP, B. (2002). The Future of the Capitalist State. Cambridge: Polity Press.

JUN, B., GERYBADZE, A. and KIM, T-Y. (2016). The Legacy of Friedrich List: The Expansive Reproduction System and the Korean History of Industrialization. Hohenheim Discussion Papers in Business, Economics and Social Sciences, No. 02-2016, Universität Hohenheim, Fakultät Wirtschafts- und Sozialwissenschaften, Stuttgart, at http://nbnresolving.de/urn:nbn:de:bsz:100-opus-11894

KIRZNER, I. (ed.) (1986). Subjectivism, Intelligibility and Economic Understanding: Essays in Honour of L. Lachman. New York: New York University Press.

LANCASTER, K. (1966). A New Approach to Consumer Theory. Journal of Political Economy 74 (2): 132-157.

LEVI-FAUR, D. (1997). Economic Nationalism: from Friedrich List to Robert Reich. Review of International Studies 23: 359-370.

LIST, F. (1841). National System of Political Economy Vol. I-III. (2005), New York, Cosimo. LUNDVALL, B.-Å. (1985). Product Innovation and User-Producer Interaction. Aalborg: Aalborg University Press.

LUNDVALL, B-Å. (ed.) (1992). National Innovation Systems: Towards a Theory of Innovation and Interactive Learning. London; Pinter, second edition (2010), London: Anthem Press.

LUNDVALL, B-Å. (2002). The Learning Economy: Challenges to Economic Theory and Policy." in Hodgson, G. (ed.): 26-47.

LUNDVALL, B-A. (2007). Innovation System Research: Where it Came From and Where it Might Go. Globelics Working Paper Series, Working Paper No. 2007-0.1.

LUNDVALL, B-Å. (ed.) 2016. The Learning Economy and the Economics of Hope. London: Anthem Press.

MACHLUP, F. (1967). Theories of the Firm: Marginalist, Behavioural, Managerial. American Economic Review 57 (1): 1-33.

MARCH, J. and SIMON, H. (1993). Organizations (2 edition): Oxford, Blackwell Publishers.

MASHALL, A. (1890.) Principles of Economics (eighth edition). London: Macmillan.

MARX, K. (1857-1861). Grundrisse. (1993) London: Penguin Books.

MARX, K. and ENGELS, F. (1848). Manifesto of the Communist Party (2015) Millennium Publications.

MCNULTY, P. J. (1968). Economic Theory and the Meaning of Competition. Quarterly Journal of Economics 82 (4): 639-656.

MINCER, J. (1958). Investment in Human Capital and Personal Income Distribution. Journal of Political Economy 66 (4): 281-302.

MITTERMAIER, K. (1986a). The Hand bebind the Invisible Hand: Dogmatic and Pragmatic Views on Free Markets and the State of Economic Theory. Unpublished PhD thesis, University of the Witwatersrand, South Africa.

MITTERMAIER, K. (1986b). “Mechanomorphism.” in Kirzner, I. (ed): 236-251.

NELSON, R.R. (1990). Capitalism as an Engine of Progress. Research Policy 19: 193-214.

NELSON, R.R. (1991). Why Do Firms Differ, and How Does it Matter? Strategic Management Journal (Special Issue: Fundamental Research Issues in Strategy and Economics) 12: 6174. 
NELSON, R.R. (1993). National Innovation Systems: A Comparative Analysis New York: Oxford University Press.

NELSON, R.R. (1998). The Agenda for Growth Theory: A Different Point of View. Cambridge Journal of Economics 22: 497-520.

NELSON, R.R. (2007). Economic Development from the Perspective of Evolutionary Economic Theory. GLOBELICS Working Paper Series, No. 2007-02, at http://www.globelics.org/wp-content/uploads/2016/05/GWP2007-02.pdf

NELSON, R.R. and WINTER, S.G. (1982). An Evolutionary Theory of Economic Change. London: Harvard University Press.

PARETO, V. (1897). The New Theories of Economics. Journal of Political Economy 5 (4): 485-502.

PERSKY, J. (1989). Retrospectives: Adam Smith's Invisible Hands. Journal of Economic Perspectives 3 (4): 195-201.

PITELIS, C. and RUNDE, J. (2017). Capabilities, Resources, Learning and Innovation: a Blueprint for a Post-classical Economics and Public Policy. Cambridge Journal of Economics 41: 679-691

PREBISCH, R. (1950). The Economic Development of Latin America and Its Principal Problems. Economic Bulletin for Latin America 7: 1-12.

QUESNAY, F. (1758) Tableau Économique. (1894) London: Macmillan and Co.

READ, J. (2009). A Genealogy of Homo-Economicus: Neoliberalism and the Production of Subjectivity. Foucault Studies 6: 25-36.

RICARDO, D. (1817). On the Principles of Political Economy and Taxation. (1821) London: John Murray, at http://www.econlib.org/library/Ricardo/ricP.html

ROBBINS, L. (1932). An Essay on the Nature and Significance of Economic Science. London: Macmillan.

SAY, J.B. (1821). A Treatise on Political Economy (1971) New York: Augustus M. Kelley Publishers.

SCERRI, M. (2008). Neoclassical Theory and the Teaching of Undergraduate Microeconomics. South African Journal of Economics 76 (4): 749-764.

SCHULTZ, T.W. (1961). Investment in Human Capital. American Economic Review 51 (1): $1-17$.

SCHUMPETER, J. (1934). The Theory of Economic Development. (2008) New Brunswick: Transaction Publishers.

SCHUMPETER, J. (1943). Capitalism, Socialism and Democracy. (2010) Oxford: Routledge. SEN, A. (1999). Development as Freedom. New York: Anchor Books.

SHAFFAEDIN, M. (2000). What did Frederick List actually say? Some Clarifications on the Infant Industry Argument. UNCTAD Discussion Paper 149 (UNCTAD/OSG/DP/149), at http://unctad.org/en/docs/dp 149.en.pdf.

SIMON, H. (1959). Theories of Decision-Making in Economics and Behavioural Science. American Economic Review 49 (3): 253-283.

SINGER, H. (1950). The Distribution of Gains between Investing and Borrowing Countries. American Economic Review, Papers and Proceedings 40 (2): 473-485.

SMITH, A. (1776). The Wealth of Nations. (2003) New York: Bantam Dell.

SOETE, L., VERSPAGEN, B. and TER WEEL, B. (2010.) Systems of Innovation. CPB Discussion Paper 138, CPB Netherlands Burean for Economic Policy Analysis, at https://www.cpb.nl/sites/default/files/publicaties/download/systems-innovation.pdf

STIGLER, G. J. (1957). Perfect Competition, Historically Contemplated. Journal of Political Economy 65 (1): 1-17.

STIGLER, G.J. (1984). Economics - The Imperial Science? Scandinavian Journal of Economics 86 (3): 301-313. 
STIGLER, G.J. and BECKER, G.S. (1977). De Gustibus non est Disputandum. American Economic Review 67 (2): 76-90.

STREECK, W. and YAMAMURA, K. (2001). The Origins of Non-Liberal Capitalism: Germany and Japan in Comparison. New York: Cornell University Press.

SWEEZY, P.M. (1943). Professor Schumpeter's Theory of Innovation. Review of Economics and Statistics 25 (1): 93-96.

VARIAVA, R. (2020). The Deployment of Racism in South Africa. Cambridge Open Engage. doi:10.33774/coe-2020-glrz9, at

https://www.cambridge.org/engage/coe/article-details/5e984688f5640a0012b2cf56.

VEBLEN, T. (1898). Why is Economics not an Evolutionary Science? Quarterly Journal of Economics 12 (4): 373-397.

VON MISES, L. (1949). Human Action: A Treatise on Economics. (1998) Auburn, Alabama: The Ludwig von Mises Institute.

WALRAS, L. (1899). Elements of Pure Economics. (English translation, 1954), London and New York: Routledge.

WHITEHEAD, A.N. (1925). Science and the Modern World. (1997) New York: Simon and Schuster.

WILLIAMSON, O. (1985). The Economic Institutions of Capitalism. New York and London: The Free Press.

WINTER, S. (2017). Pursuing the Evolutionary agenda in Economics and Management Research. Cambridge Journal of Economics (41): 721-747.

YOUNG, R. (ed.) (1981). Unifying the Text: A Post-Structuralist Reader. London: Routledge and Kegan Paul. 